\title{
Antigen vehiculization particles based on the $Z$ protein of Junin virus
}

\author{
Cristina S Borio ${ }^{1 *}$, Marcos F Bilen², Marcelo H Argüelles ${ }^{3}$, Sandra E Goñi ${ }^{1}$, Javier A Iserte', Graciela Glikmann ${ }^{3}$ \\ and Mario E Lozano'
}

\begin{abstract}
Background: Arenavirus matrix protein Z plays an important role in virus budding and is able to generate enveloped virus-like-particles (VLPs) in absence of any other viral proteins. In these VLPs, Z protein is associated to the plasma membrane inner surface by its myristoyl residue. Budding induction and vesicle formation properties can be exploited to generate enveloped VLPs platform. These structures can be designed to carry specific antigen in the inner side or on the surface of VLPS.

Vaccines based on VLPs are a highly effective type of subunit vaccines that mimic the overall structure of virus particles in absence of viral nucleic acid, being noninfectious.

In this work we assayed the capacity of Junin Z protein to produce VLPs carrying the green fluorescent protein (eGFP), as a model antigen.

Results: In this report the Junin Z protein ability to produce VLPs from 293T cells and its capacity to deliver a specific antigen (eGFP) fused to $Z$ was evaluated. Confocal microscopy showed a particular membrane bending in cells expressing $Z$ and a spot welded distribution in the cytoplasm. VLPs were detected by TEM (transmission electron microscopy) and were purified from cell supernatant. The proteinase protection assay demonstrated the VLPs integrity and the absence of degradation of the fused antigen, thus indicating its internal localization. Finally, immunization of mice with purified VLPs produced high titres of anti-eGFP antibodies compared to the controls.
\end{abstract}

Conclusions: It was proved that VLPs can be generated from cells transfected with a fusion Junin virus Z-eGFP protein in absence of any other viral protein, and the capacity of Z protein to support fusions at the C-terminal, without impairing its budding activity, allowing vehiculization of specific antigens into VLPs.

Keywords: Virus-like particles, Antigen delivery, Arenavirus, Z protein

\section{Background}

The Arenavirus $\mathrm{Z}$ protein is considered the matrix protein of this virus family [1]. It comprises three main regions that contain different domains: the Amino-end (Myristoylation Domain), the Core (RING Domain), and Carboxyl-end (Late Domain) [2]. Among the several functions described for this small protein $(11 \mathrm{kDa})$ it can be highlighted its inhibitory effect on viral RNA replication and transcription through its interaction with the $\mathrm{L}$ protein $[3,4]$ as well as its capability of interacting and recruiting the viral nucleoprotein $[5,6]$. Other interesting proposed properties may include: translation inhibition

\footnotetext{
* Correspondence: cristinaborio@gmail.com

'LIGBCM-AVEZ. Department of Science and Technology, Universidad

Nacional de Quilmes, Bernal, Buenos Aires, Argentina

Full list of author information is available at the end of the article
}

through interactions with cellular factors like the promyelocytic leukemia protein (PML) [7], the eukaryotic translation initiation factor eIF4E [8], and downregulation of IRF7 expression in arenavirus-infected plasmacytoid dendritic cells (pDCs) [9]. At the late steps of the infection cycle, $\mathrm{Z}$ is the driving force of arenaviral budding [10]. This activity is mainly conducted by two motifs found at the $\mathrm{Z} \mathrm{C}$-terminal domain, PTAP in the New World arenaviruses and/or PPPY in the Old World arenaviruses. These motifs, called late domains, mediate the interaction with cellular factors of the multivesicular body pathway (MVB) and drive the viral budding from the plasma membrane of arenaviruses and other viruses $[9,11]$. It has been previously reported that the expression of the $Z$ protein alone is sufficient to induce the release of Z-containing enveloped particles in Lassa fever

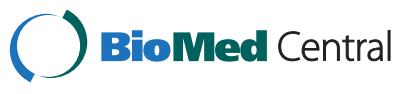


virus [10,12], Mopeia [6], Tacaribe and Junín [13,14]. A myristoylation in the glycine 2 residue is an important modification of $\mathrm{Z}$. Mutations at this site completely abolish its capacity of driving the budding process, reflecting the importance of the interaction with membrane to promote budding $[15,16]$. For other matrix proteins, it has been reported that insertion of epitopes with a length of 20-30 amino acids still allows VLPs production and does not interfere with its budding activity [17].

Budding induction and vesicle formation properties can be exploited to generate enveloped VLPs. These VLPs structures can be designed to carry $\mathrm{T}$ or $\mathrm{B}$ cell epitopes which can be recognized by mature $\mathrm{T}$ and $\mathrm{B}$ lymphocytes from adaptive immune response [17]. Currently, many successful viral vaccines are predominantly based on live attenuated or inactivated viruses. The induced immune responses are similar to those from natural infections and often these vaccines are effective after a single dose. However, the reversion of attenuated viruses and incomplete inactivation of killed virus vaccines are the major manufacturing concerns. Subunit vaccines are safer than live attenuated and inactivated vaccines, but often single proteins, when expressed and purified in the absence of other viral components, are less immunogenic than those that are incorporated into infectious particles. In this sense, the vaccines based on VLPs are a highly effective type of subunit vaccines that mimic the overall structure of virus particles in absence of viral nucleic acid, being absolutely noninfectious [18].

In this work we assayed the capacity of the Junin $\mathrm{Z}$ protein as a VLP-forming protein carrying the green fluorescent protein (eGFP) as a model antigen. To accomplish this, we cloned and expressed in mammalian 293T cells the recombinant Z-eGFP from the $\mathrm{Z}$ protein of Junín Virus Candid\#1. In addition, we demonstrated that the fusion of $\mathrm{Z}$ protein to a heterologous protein like eGFP, does not interfere with its budding capacity in mammal cells, evaluating the VLP generation by microscopic and immunologic methodologies. Furthermore, we produced and purified Z-eGFP derived VLPs to evaluate their ability to induce an immune response in vivo.

\section{Results}

\section{Expression of Z-eGFP on 293T cells}

The pZ-eGFP plasmid was constructed based on the commercial vector pEGFP-N3 (Clontech) for mammalian cell expression of Z-eGFP protein under the regulation of CMV promoter. Transient transfection of 293T cells with this plasmid resulted in a high level expression of Z-eGFP protein $(37.9 \mathrm{kDa})$. We analyzed the expression of both Z-eGFP and eGFP $(26.9 \mathrm{kDa})$ proteins by confocal fluorescence microscopy and the distributions were similar in both cases, only with minor differences (Figure 1). In Z-eGFP transfected cells (Figure 1B) we observed a dotted pattern of fluorescence distributed around the cytoplasm (close to the plasma membrane) which was completely absent in control cells (Figure 1A). These patterns were clearly ascertained in optical sections (Figure 1B' and Additional file 1: Figure S1A). The main difference between Z-eGFP and eGFP expression resides in the plasma membrane bending in Z-eGFP transfected cells. This phenomenon is clearly observed on the $\mathrm{Z}$ stack as well as in the optical sections (Figure 1B') but it was also absent in the corresponding control cells (Figure 1A and $\left.1 \mathrm{~A}^{\prime}\right)$.

\section{Purification of Z-eGFP virus like particles}

In order to determine if the fluorescent signal corresponded to the full length Z-eGFP protein, the cell lysate fraction was analyzed by western blot and the $\mathrm{Z}$ protein was detected (Figure 2A), with a molecular weight of approximately $38 \mathrm{kDa}$, corresponding to the size of the fusion protein. To detect virus like particle formation, we analyzed the pellet after ultracentrifugation through a sucrose cushion of supernatants harvested from pZ-eGFP transfected cells and, as shown in Figure 2A, we localized the Z-eGFP in the pelleted material.

To analyze if Z-eGFP was included into organized structures resembling VLPs, the pellet obtained after ultracentrifugation was subjected to a protease protection assay (Figure 2B). In this assay, untreated samples were compared to samples treated either with proteinase $\mathrm{K}$ alone or with proteinase $\mathrm{K}$ in the presence of Triton X-100 to allow permeabilization. Treatment with proteinase $\mathrm{K}$ had no effect on the Z-eGFP protein, whereas the addition of Triton X-100 destroyed the lipid envelope and therefore enabled the degradation of Z-eGFP by proteinase K. These results clearly demonstrate that Z-eGFP is located in the inner region of VLPs and is preserved from degradation by the lipid membrane. Finally, this sample was analyzed by transmission electron microscopy with immunogold labeling (Figure $2 \mathrm{C}$ and D, and Additional file 2: Figure S2), which provided evidence for the presence of irregular electron dense structures of 40 to $150 \mathrm{~nm}$ of diameter coinciding with the expected appearance of VLPs labeled with gold particles. These particles were absent in the control group (data not shown). Furthermore, in Additional file 2: Figure S2 we observed a structure, compatible with membrane debris, containing Z-EGFP. Also in the TEM picture, unlabeled VLPs were observed, probably due to the sample preparation protocol, which lacks a permeabilization step.

\section{GFP-specific IgG antibody response}

To determine the humoral immune response to GFP, Balb/C mice were immunized with the previously purified Z-eGFP VLPs, in the absence of adjuvant. Total GFP-specific IgG antibodies were assayed by ELISA on 


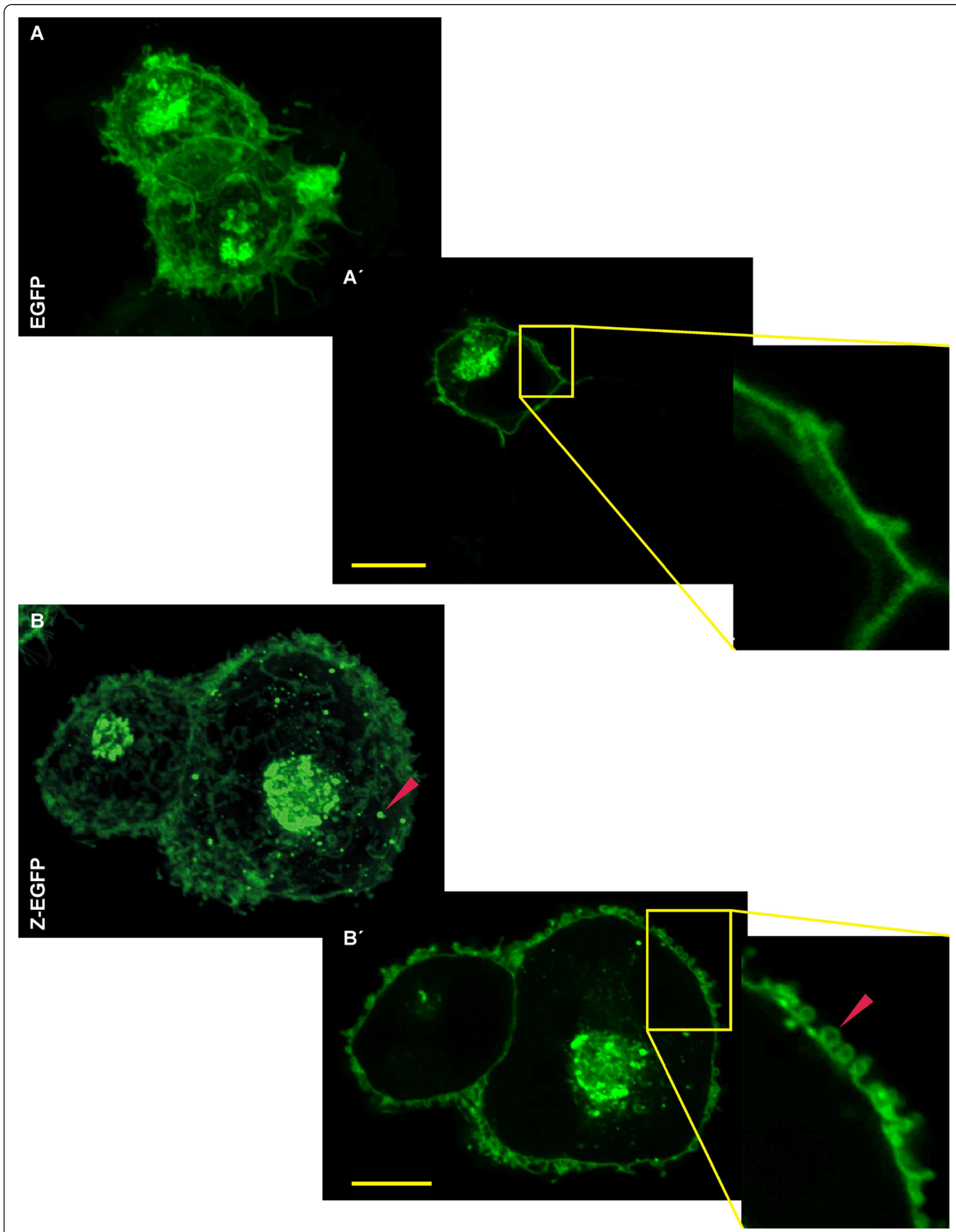

Figure 1 (See legend on next page.) 
(See figure on previous page.)

Figure 1 Confocal fluorescence microscopy of 293T transient transfected cells. A. Z-serie of 293T control cells transfected with peGFP-N3, followed by an optical section and digital zoom of the yellow rectangle. A'. Optical section. B. Z-serie of 293T cells transfected with pZ-eGFP, followed by an optical section and digital zoom. $\mathbf{B}^{\prime}$. Optical section. Red arrows indicate the membrane bending and the spot welded distribution. The bar in each figure represents $10 \mu \mathrm{m}$.

GFP coated plates (Figure 3). After day 21 most of the mice belonging to VLPs immunized group had generated an immune response to GFP, while maximum titres were achieved by day 35 (1:1000 on average). The arithmetic means of each group at day 35 were plotted in Figure 3, where it was possible to evidence that the $\operatorname{IgG}$ response obtained by Z-eGFP VLPs was significantly more robust than the soluble antigen, or the Triton $\mathrm{X}$ 100 treated Z-eGFP VLPs.

\section{Discussion}

In this study we analyzed the Junin Virus Z-eGFP fusion protein expression and, in more detail, its budding capacity on 293T cells, aiming to the development of a platform for antigen vehiculization.

First, we assayed the transient transfection of 293T cells with pZ-eGFP (Figure 1), where we detected high levels of Z-eGFP expression with a homogeneous distribution. However, the resolution achieved by confocal microscopy allowed us to detect some regions of concentrated protein which are located near the nucleus, where it would be expected to find the endoplasmic reticulum membrane system, and a spot welded distribution around the cytoplasm. These spots can be explained by the previously described interaction between $\mathrm{Z}$ and the PML protein. The PML forms nuclear bodies, and it has been shown that $\mathrm{Z}$ alone is sufficient to redistribute PML from a nuclear punctuate to a cytoplasmic punctuate pattern [7]. Also these agreggates could be late endosomal compartments such as multivesicular bodies (MVB) containing intraluminal vesicles derived from Z-eGFP, as it has been described for retroviruses [19]. These vesicles would then be transported to the plasma membrane, where the fusion of the MVB allowed the release of the intraluminal vesicles, in this case the Z-eGFP derived VLPs. This hypothesis of ZeGFP associated to membrane vesicles is supported by the fact that arenavirus $\mathrm{Z}$ protein is myristoylated. The wild type distribution of $\mathrm{Z}$ protein is spot welded around the cytoplasm and homogeneously distributed across the plasma membrane. However, in studies with a mutant $\mathrm{Z}$ protein at the myristoylation essential amino acid (glycine 2) a diffused pattern mainly with a perinuclear distribution was shown [15]. The same was demonstrated for the gag protein of HIV [20]. Therefore it has been proved that $\mathrm{Z}$ localization is membrane associated [15],
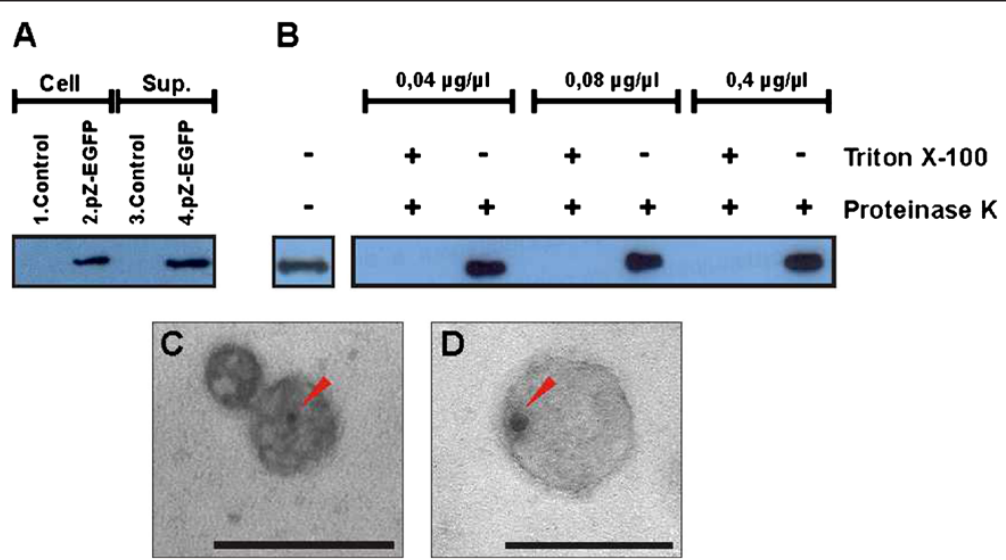

Figure 2 Z-eGFP virus like particles detection and characterization. A. Western Blot with anti-Z inmunoglobulines of Z-eGFP expression in 293T cells. Lane 1. 293T untransfected monolayer (control). 2. 293T monolayer transfected with pZ-eGFP. (Cell) Cell lysate 3. Pellet of the ultracentrifugated supernatant of untransfected 293T cells (control). 4. Pellet of the ultracentrifugated supernatant of 293T cells transfected with pZ-eGFP. (Sup) pelleted material from supernatant. B. Protease protection assay of Z-protein-containing particles in the supernatant of pZ-eGFP transfected 293T cells. Western Blot with anti-Z inmunoglobuline of the pellet of the ultracentrifugated supernatant of transfected cells, treated with proteinase $\mathrm{K}$ to final concentration of $0.04 \mu \mathrm{g} / \mu \mathrm{l}, 0.08 \mu \mathrm{g} / \mu \mathrm{l}$ and $0.4 \mu \mathrm{g} / \mu \mathrm{l}$, with or without Triton X-100, or untreated (lane 1). C and D. Transmission electron microscopy with immunogold labelling of the pellet obtained by ultracentrifugation through a sucrose cushion of the supernatant of pZ-eGFP transfected cells. The red arrow indicates the gold labelling. The bar in each figure represents $100 \mathrm{~nm}$. 


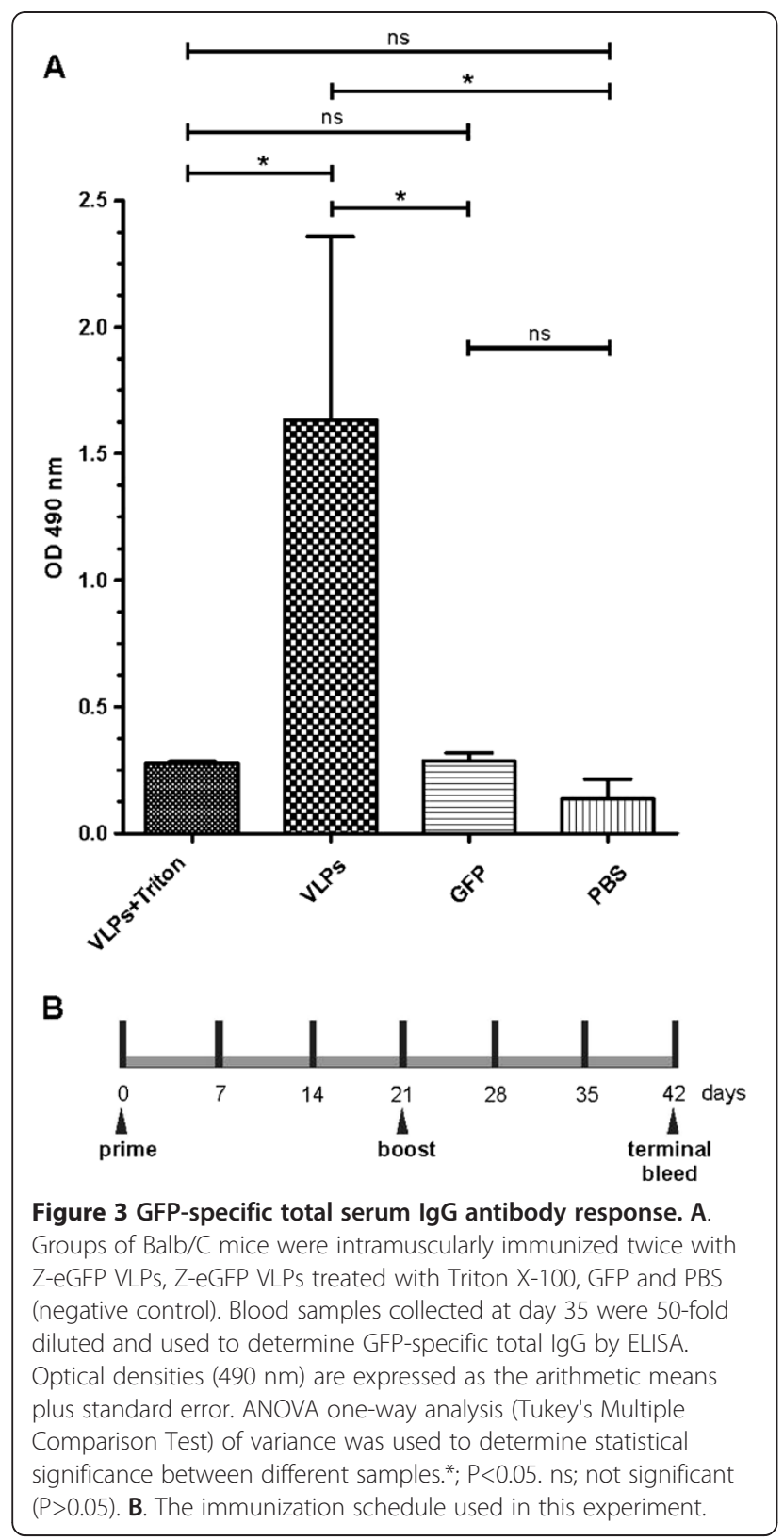

and it has been postulated that vesicles transport the protein from the place of synthesis and myristoylation, to the plasma membrane. However, Kentis et al.(2002) [21] described that bacterially expressed LCMV Z protein appeared to self assemble into ordered protein structures of $500 \AA$ that approximate in size to the protein aggregates observed in vivo. These arrangements were obtained in vitro from purified $\mathrm{Z}$ protein expressed in a prokaryotic system where some posttranslational modifications, like myristoylation, do not occur.

On the other hand, the morphology of the membrane on cells transfected with pZ-eGFP clearly differed from control cells (eGFP). In the first case, it was possible to observe the bending of the plasma membrane or budding initiation regions, suggesting an intact budding activity of Z-eGFP protein. This membrane bending has also been observed using confocal fluorescence microscopy for other viruses like AcMNPV baculovirus [22] and MLV retrovirus [23].

Results depicted in Figure 2 showed that recombinant Z-eGFP protein was able to form vesicles at the plasma membrane in a similar way as $\mathrm{Z}$ protein alone, suggesting that the fusion of a 238 amino acid protein, like eGFP, did not impair the budding capacity of Z. It is a common feature of matrix polypeptides like HIV gag protein or influenza M1 protein to conserve their budding capability when they are fused to small epitopes [17]. However, it is not frequent that proteins mainly involved in budding activities can support the introduction of large proteins without having its budding capacity impaired. Capul and de la Torre (2008) [24] have recently described that the fusion of the small (185 amino acids) luciferase from Gaussia princeps to Arenavirus $\mathrm{Z}$ protein resulted in a quimeric protein that retained budding activity. Considering the budding capacity of quimeras containing $\mathrm{Z}$ from Junín virus and a heterologous protein (in this study, GFP), other proteins could be coupled to $\mathrm{Z}$ generating a tool for antigen delivery.

According to the electron microscopy images the VLPs produced by Junin virus $\mathrm{Z}$ protein in $293 \mathrm{~T}$ cells have a relative size similar to the Junin virion (50 to $100 \mathrm{~nm}$ ) (Figure $2 \mathrm{C}$ and $\mathrm{D}$ ) as well as an irregular shape, which is consistent with observations made for other arenaviruses $[12,25,26]$.

Some important features for an immunization delivery vehicle are a safe generation procedure in a low biosafety level lab and the protection of the internal molecules from degradation. According to this, VLPs lack of any replicative function and the results show that particles are closed and internal polypeptides (in this study, Z-eGFP) protected from extracellular proteases. In order to analyze the VLPs immunization capacity, an assay using Balb/C mice was performed. A satisfactory humoral immune response was induced against the eGFP contained within the VLPs. This response was detected within a few days after the booster immunization reaching a maximum title by day 35 . However, in the same conditions, neither completely disrupted Z-eGFP VLPs nor purified eGFP immunized mice showed a detectable IgG response (Figure 3), suggesting a better performance for intact VLPs.

There are many reports showing that the particulate nature improves the immunogenicity of the proteins included in or delivered by VLPs $[27,28]$. So, it is not surprising that VLPs described here improved the response against the antigen contained within the particle. 
As mentioned before, an equal dose of purified soluble protein did not induce a detectable humoral response. Traditional VLPs as well as pathogens have highly repetitive surfaces and usually induce strong antibody responses because they can cross-link B cell receptors with high efficiency [29]. The vesicles generated here show an important difference with other VLP systems since the protein is contained mainly within the vesicle, as shown by the protease protection assay (Figure 2B). In order to induce production of antibodies, protein must be exposed so that it can be recognized by B cells and this might happen by partial disruption of VLP membrane with exposition of antigen and direct stimulation of B cells. Although the size of VLPs (50-100 nm) would allow their access to lymphatic vessels and their transport directly to draining lymph nodes $[28,30]$ we can not exclude the possibility that cell-associated transport of native protein might be involved in activation of B cells as well. This phenomenon, that involves internalization and recycling of native antigen to cell surface, has been described for macrophages associated to the subcapsular sinus [31-33], dendritic cells [34-36] and follicular dendritic cells [37]. This mechanism would be important in dendritic cells, which have both nondegradative and degradative antigen uptake pathways, allowing them not only to prime $\mathrm{T}$ cells but also to present native antigen to $\mathrm{B}$ cells. Some authors have demonstrated that this mechanism is dependent of interaction of immune complexes with inhibitory Fc receptors [38] but a recent publication from Le Roux et al. demonstrates that DCs have the ability to regurgitate unprocessed antigen which poses another B-cell activation mechanism [39].

Any of these possibilities or more probably a combination of several of them would allow inducing an antibody response against eGFP, despite the fact that the protein is contained within the VLPs (Figure 3). Similar results were obtained by Cubas et al. (2009) [40] after immunizing mice with SHIV VLPs (SIV Gag + HIV SF162 Env), since they observed an antibody response both to external envelope protein (Env) and to the internal gag protein.

Although the immunological response induced needs further characterization the results suggest that this system might be used as a platform to deliver foraneous antigens or even chimeric heterologous antigens, which can induce an antibody response even in the absence of any exogenous adjuvant.

\section{Conclusions}

In summary, the results obtained here indicate that $\mathrm{Z}$ protein from Junin virus can support fusions at the $C$ terminal without impairing its budding activity. This is suitable for the production of VLPs and could be used for vehiculization of heterologous proteins from other pathogens acting as promising immune stimulators.

\section{Methods}

\section{Cell culture}

For the transient expression of recombinant $\mathrm{Z}$ protein we used human embryonic kidney cells transformed with adenovirus type 5 DNA, designated 293T [41]. Cells were grown in RPMI 1640 (Invitrogen) supplemented with $10 \%$ fetal bovine serum at $37^{\circ} \mathrm{C}$ in a $5 \% \mathrm{CO}_{2}$ atmosphere.

\section{Transfection of 293 T cells}

Cell monolayers (80\% confluence) were washed with PBS and transfected with the plasmid using PolyFect transfection reagent (Qiagen) following the manufacter instructions. The ratio of DNA $(\mu \mathrm{g})$ to PolyFect $(\mu \mathrm{l})$ was 1:10 for both $30 \mathrm{~mm}$ dishes (2 $\mu \mathrm{g}$ of DNA) and $60 \mathrm{~mm}$ dishes $(8 \mu \mathrm{g}$ of DNA). In all cases the DNA was previously purified with Qiagen Plasmid Mini kit. The samples were analyzed by Western blot and Fluorescence Microscopy as described below, 48 and $72 \mathrm{~h}$ post-transfection.

\section{Fluorescence microscopy}

Transfected 293T cells with either pZ-eGFP or peGFPN3 were grown on glass cover slides as indicated above. After $48 \mathrm{~h}$, cells were fixed with $4 \%$ (wt/vol) formaldehyde in PBS for $15 \mathrm{~min}$ at room temperature. Images were captured using a confocal microscope Olympus FluoView FV1000 at 600x magnification, and analyzed using Olympus FluoView 2.0 software.

\section{Western blot}

The samples were separated by SDS-PAGE (12-15\% polyacrylamide gel) and blotted onto nitrocellulose membranes (Hybond $\mathrm{P}+$, Amersham Pharmacia) in Trisglycine buffer containing $20 \%(\mathrm{v} / \mathrm{v})$ methanol. To avoid non-specific binding of the antibodies, the membranes were blocked by incubating with $5 \%(\mathrm{w} / \mathrm{v})$ skimmed powder milk in PBS for $2 \mathrm{~h}$ at $37^{\circ} \mathrm{C}$. For the primary antibody incubation the blocked membrane was probed with a $1 / 1,000$ dilution of a polyclonal antiserum specific for the $\mathrm{Z}$ protein on PBS $2 \%$ casein at $37^{\circ} \mathrm{C}$ for $1 \mathrm{~h}$, followed by a horse radish peroxidase conjugated goat antirabbit IgG (Santa Cruz Biotechnology) incubation, diluted $1 / 10,000$ on PBS $0.1 \%$ Tween -20 at $37^{\circ} \mathrm{C}$ for $1 \mathrm{~h}$. Between steps, the membrane was washed three times with PBS 5 minutes. For Dot blot assays, the samples were vacumm blotted onto a nitrocellulose membrane and treated as mentioned for Western blot.

\section{VLPs purification by sucrose cushion ultracentrifugation} Supernatants of previously transfected cells were collected and clarified from cellular debris by low speed 
centrifugation at $2800 \mathrm{~g}$, at room temperature for $20 \mathrm{~min}$. After clarification, VLPs present in supernatants were pelleted through a $30 \%(\mathrm{w} / \mathrm{v})$ sucrose cushion at 96,000 $\mathrm{g}$ for $2 \mathrm{~h}$ at $4^{\circ} \mathrm{C}$. Pellets were then resuspended in PBS. Corresponding monolayers were harvested in ProteoJET Mammalian Cell Lysis Reagent (Fermentas) and used as control samples in Western blot assays.

In order to obtain large quantities of Z-eGFP VLPs, multiple $75 \mathrm{~cm}^{2}$ culture flasks at $80 \%$ confluence were transfected with pZ-eGFP and culture media was collected up to the third passage. Following the first step of ultracentrifugation the pellets were pooled and resuspended on PBS for further treatment with proteinase K. An extra ultracentrifugation step $\left(96000 \mathrm{~g}\right.$ for $2 \mathrm{~h}$ at $4^{\circ} \mathrm{C}$ ) was made for the removal of the proteinase $\mathrm{K}$, foreign proteins and defective VLPs from the preparation. The pellet was resuspended in PBS and used to immunize mice.

\section{Protease protection assay}

Pellets obtained from pZ-eGFP transfected cells were treated with $0.4 \mu \mathrm{g}, 0.08 \mu \mathrm{g}$ or $0.04 \mu \mathrm{g}$ of proteinase $\mathrm{K}$ (Fermentas) alone or with a combination of proteinase $\mathrm{K}$ and $1 \%$ Triton $\mathrm{X}-100$ for $30 \mathrm{~min}$ at $37^{\circ} \mathrm{C}$. After the incubation the reaction was stopped with $100 \mathrm{mM}$ PMSF and boiled for 10 minutes. Samples were then analyzed by SDS-PAGE and Western Blot.

\section{Transmission electron microscopy (TEM)}

A drop of the purified VLPs suspension was deposited on a formvar-carbon-coated nickel grid for $1 \mathrm{~min}$. The samples were negatively stained with $2 \%$ phosphotungstic acid and examined in a Phillips EM 301 electron microscope.

\section{TEM-immunogold}

After ultracentrifugation, VLPs were resuspended in PBS containing 4\% paraformaldehyde. A drop of the suspension was deposited on a formvar-carbon-coated nickel grid for 1 min and washed six times with PBS. The grids were then treated with dilution buffer i.e. PBS containing $0.5 \%$ bovine serum albumin and $0.1 \%$ Tween during 30 min followed by washing with PBS. Grids were then incubated for $1 \mathrm{~h}$ with rabbit anti-Z polyclonal IgG 1/300 in dilution buffer for 1 hour. The grids were washed six times with PBS and incubated further for $1 \mathrm{~h}$ with a donkey anti-rabbit IgG antibody coupled to $12 \mathrm{~nm}$ gold beads (Invitrogen) $1 / 20$ in dilution buffer. Finally, grids were washed six times with PBS, fixed for $10 \mathrm{~min}$ in $2 \%$ glutaraldehyde, negatively stained with uranil acetate and examined by TEM.

\section{Mice immunization}

Male inbred Balb/C mice aged 6 weeks (4 per group) were immunized intramuscularly with $5 \mu \mathrm{g}$ of Z-eGFP
VLPs in $100 \mu \mathrm{l}$ PBS, twice threat a three weeks interval. To determine the effect of VLP integrity on its inmunogenicity, VLPs were disrupted by treatment with $1 \%$ Triton $\mathrm{X}-100$ and used to immunize mice as a control group. Two additional controls groups were included: mice immunized with either $5 \mu \mathrm{g}$ of soluble GFP protein or PBS alone. Blood samples were collected on days 0,7 , 14, 21, 28 and 35 for analysis of immune responses and mice were sacrified on day 42 postimmunization. Sera were stored at $-20^{\circ} \mathrm{C}$ until use.

\section{Evaluation of humoral immune response}

Ninety six-well microtiter plates (Nunc, Maxisorpt Glostrup, Denmark) were coated with $0.5 \mu \mathrm{g}$ of GFP protein in coating buffer, ie: $0.1 \mathrm{M}$ bicarbonate buffer $\mathrm{pH}$ 9.6, overnight at $4^{\circ} \mathrm{C}$. Plates were blocked with $\mathrm{PBS}$ containing $1 \%$ of casein at $37^{\circ} \mathrm{C}$, for $1 \mathrm{~h}$. After this and the following steps the plates were washed three times with washing solution, i.e.: PBS, $0.5 \mathrm{M} \mathrm{NaCl}, 0.2 \%$ (v/v) Triton X-100. Fifty microliters of each serum sample from immunized animals diluted in sample buffer (i.e.: $1 \%(\mathrm{w} / \mathrm{v})$ casein in washing solution) were added to the antigen coated wells and incubated at $37^{\circ} \mathrm{C}$ for $1 \mathrm{~h}$. Bound antibodies were detected with peroxidaseconjugated anti-mouse IgG (Pierce) in sample buffer at $37^{\circ} \mathrm{C}$ for $1 \mathrm{~h}$ and were then revealed with orthophenylene diamine (OPD, Sigma Chemicals Co) [42].

\section{Additional files}

Additional file 1: Figure S1. Individual optical sections of transfected $293 T$ cells. A. Optical sections of pZ-eGFP transfected cells, from section 21-67. B. Optical sections of control peGFP transfected cells, from section 16-61. The thickness of the optical sections is $3.9 \mathrm{~nm}$.

Additional file 2: Figure S2. Transmission electron microscopy with immunogold labeling. Transmission electron microscopy with immunogold labeling of the purified VLPs by ultracentrifugation through a sucrose cushion. Z-EGFP VLPS are pointed with red arrows, and similar structures that are not immunogold labeled are pointed with empty arrows. (The VLP indicated with * is amplified in Figure $2 \mathrm{C}$ ). The bar represents $100 \mathrm{~nm}$.

\section{Abbreviations}

CMV: Cytomegalovirus; MVB: Multivesicular bodies; pDC: Plasmacytoid dendritic cells; PML: Promyelocytic Leukemia Protein; TEM: Transmission electron microscopy; VLP: Virus-like-particles.

\section{Competing interest}

The authors declare that they have no competing interests.

\section{Authors' contributions}

CSB carried out all the experiments and drafted the manuscript; MFB design the molecular experiments and participated in the general direction; MHA designed the Immunological tests and helped with the analysis and interpretation of data; SEG participated in the design and realization of the manuscript; JAI collaborated with the preparation of materials needed for all assays; GG participated in the analysis and drafting of the manuscript; MEL conceived the work and coordinated the drafting of the manuscript. All authors read and approved the final manuscript. 


\section{Authors' information}

CSB, MFB, MHA, SEG, JAl, GG, and MEL are research-professors of the Universidad Nacional de Quilmes. CSB holds a doctoral fellowship of Consejo Nacional de Ciencia y Tecnología (CONICET). MFB is member of the Research Career of CONICET. SEG holds a postdoctoral fellowship of CONICET. JAI is professor of the Universidad Nacional Arturo Jauretche. MEL is member of the Research Career of CONICET.

\section{Acknowledgements}

This work was supported by research funds PICT2007-38138 and PICT20100880 from Agencia Nacional de Promoción Científica y Técnica (ANPCyT), PIP 11420100100285 from CONICET, and PMMByAB from Universidad Nacional de Quilmes. The plasmid pZ-eGFP was kindly provided by Dr. Agustin Ure and Dr. Ricardo Gomez. The authors acknowledge Lic. Laura Esteban for her help in the immunological assays, to the National Academy of Medicine for their help in the confocal microscope assays, and to the collegues of LIGBCM-AVI for their collaboration.

\section{Author details}

'LIGBCM-AVEZ. Department of Science and Technology, Universidad Nacional de Quilmes, Bernal, Buenos Aires, Argentina. ${ }^{2}$ LIGBCM-AVI. Department of Science and Technology, Universidad Nacional de Quilmes, Bernal, Buenos Aires, Argentina. ${ }^{3}$ Laboratory of Immunology and Virology. Department of Science and Technology, Universidad Nacional de Quilmes, Roque Saenz Peña 352, Bernal, Buenos Aires B1876BXD, Argentina.

Received: 29 May 2012 Accepted: 25 October 2012

Published: 2 November 2012

\section{References}

1. Perez M, Craven RC, de la Torre JC: The small RING finger protein Z drives arenavirus budding: implications for antiviral strategies. Proc Natl Acad Sci USA 2003, 100(22):12978-12983.

2. Goni SE, Borio CS, Romano FB, Rota RP, Pilloff MG, Iserte JA, Tortorici MA, Stephan Bl, Bilen MF, Ghiringhelli PD, et al: Expression and purification of Z protein from Junin virus. J Biomed Biotechnol 2010, 2010:970491.

3. Wilda M, Lopez N, Casabona JC, Franze-Fernandez MT: Mapping of the tacaribe arenavirus Z-protein binding sites on the $L$ protein identified both amino acids within the putative polymerase domain and a region at the $\mathrm{N}$ terminus of $\mathrm{L}$ that are critically involved in binding. J Virol 2008, 82(22): 11454-11460.

4. Lopez N, Jacamo R, Franze-Fernandez MT: Transcription and RNA replication of tacaribe virus genome and antigenome analogs require $\mathrm{N}$ and L proteins: Z protein is an inhibitor of these processes. J Virol 2001, 75(24):12241-12251.

5. Neuman BW, Adair BD, Burns JW, Milligan RA, Buchmeier MJ, Yeager M: Complementarity in the supramolecular design of arenaviruses and retroviruses revealed by electron cryomicroscopy and image analysis. Virol 2005, 79(6):3822-3830.

6. Shtanko O, Imai M, Goto H, Lukashevich IS, Neumann G, Watanabe T, Kawaoka Y: A role for the $C$ terminus of Mopeia virus nucleoprotein in its incorporation into Z protein-induced virus-like particles. J Virol 2010, 84(10):5415-5422.

7. Borden KL, Campbell Dwyer EJ, Salvato MS: An arenavirus RING (zincbinding) protein binds the oncoprotein promyelocyte leukemia protein (PML) and relocates PML nuclear bodies to the cytoplasm. J Virol 1998, 72(1):758-766

8. Kentsis A, Dwyer EC, Perez JM, Sharma M, Chen A, Pan ZQ, Borden KL: The RING domains of the promyelocytic leukemia protein PML and the arenaviral protein $\mathrm{Z}$ repress translation by directly inhibiting translation initiation factor elF4E. Journal Of Molecular Biology 2001, 312(4):609-623.

9. Urata S, de la Torre JC: Arenavirus budding. Adv Virol 2011, 2011:180326.

10. Strecker T, Eichler R, Meulen J, Weissenhorn W, Dieter Klenk H, Garten W, Lenz O: Lassa virus $\mathrm{Z}$ protein is a matrix protein and sufficient for the release of virus-like particles [corrected]. J Virol 2003, 77(19):10700-10705

11. Urata S, Noda T, Kawaoka Y, Yokosawa H, Yasuda J: Cellular factors required for Lassa virus budding. J Virol 2006, 80(8):4191-4195.

12. Eichler R, Strecker T, Kolesnikova L, ter Meulen J, Weissenhorn W, Becker S, Klenk HD, Garten W, Lenz O: Characterization of the Lassa virus matrix protein Z: electron microscopic study of virus-like particles and interaction with the nucleoprotein (NP). Virus Res 2004, 100(2):249-255.
13. Casabona JC, Levingston Macleod JM, Loureiro ME, Gomez GA, Lopez N: The RING domain and the L79 residue of $Z$ protein are involved in both the rescue of nucleocapsids and the incorporation of glycoproteins into infectious chimeric arenavirus-like particles. J Virol 2009, 83(14):7029-7039.

14. Urata S, Yasuda J, de la Torre JC: The z protein of the new world arenavirus tacaribe virus has bona fide budding activity that does not depend on known late domain motifs. J Virol 2009, 83(23):12651-12655.

15. Strecker T, Maisa A, Daffis S, Eichler R, Lenz O, Garten W: The role of myristoylation in the membrane association of the Lassa virus matrix protein Z. Virol J 2006, 3:93.

16. Perez M, Greenwald DL, de la Torre JC: Myristoylation of the RING finger Z protein is essential for arenavirus budding. J Virol 2004, 78(20):11443-11448.

17. Chackerian B: Virus-like particles: flexible platforms for vaccine development. Expert Rev Vaccines 2007, 6(3):381-390.

18. Roy P, Noad R: Virus-like particles as a vaccine delivery system: myths and facts. Hum Vaccin 2008, 4(1):5-12.

19. McDonald B, Martin-Serrano J: No strings attached: the ESCRT machinery in viral budding and cytokinesis. J Cell Sci 2009, 122(Pt 13):2167-2177.

20. Zhou W, Parent L, Wills JW, Resh MD: Identification of a membranebinding domain within the amino-terminal region of human immunodeficiency virus type $1 \mathrm{Gag}$ protein which interacts with acidic phospholipids. J Virol 1994, 68(4):2556-2569.

21. Kentsis A, Gordon RE, Borden KL: Self-assembly properties of a model RING domain. Proc Natl Acad Sci USA 2002, 99(2):667-672.

22. Ohkawa T, Volkman LE, Welch MD: Actin-based motility drives baculovirus transit to the nucleus and cell surface. J Cell Biol 2010, 190(2):187-195.

23. Gladnikoff M, Shimoni E, Gov NS, Rousso I: Retroviral assembly and budding occur through an actin-driven mechanism. Biophys J 2009, 97(9):2419-2428.

24. Capul AA, de la Torre JC: A cell-based luciferase assay amenable to highthroughput screening of inhibitors of arenavirus budding. Virology 2008 382(1):107-114.

25. Murphy FA, Webb PA, Johnson KM, Whitfield SG, Chappell WA: Arenoviruses in Vero cells: ultrastructural studies. J Virol 1970, 6(4):507-518.

26. Branco LM, Grove JN, Geske FJ, Boisen ML, Muncy IJ, Magliato SA, Henderson LA, Schoepp RJ, Cashman KA, Hensley LE, et al: Lassa virus-like particles displaying all major immunological determinants as a vaccine candidate for Lassa hemorrhagic fever. Virol J 2010, 7:279.

27. Ramqvist $T$, Andreasson $K$, Dalianis T: Vaccination, immune and gene therapy based on virus-like particles against viral infections and cancer. Expert Opin Biol Ther 2007, 7(7):997-1007.

28. Bachmann MF, Jennings GT: Vaccine delivery: a matter of size, geometry, kinetics and molecular patterns. Nat Rev Immunol 2010, 10(11):787-796.

29. Bachmann MF, Rohrer UH, Kundig TM, Burki K, Hengartner H, Zinkernagel $\mathrm{RM}$ : The influence of antigen organization on $B$ cell responsiveness. Science 1993, 262(5138):1448-1451.

30. Singh M, Chakrapani A, O'Hagan D: Nanoparticles and microparticles as vaccine-delivery systems. Expert Rev Vaccines 2007, 6(5):797-808.

31. Szakal AK, Holmes KL, Tew JG: Transport of immune complexes from the subcapsular sinus to lymph node follicles on the surface of nonphagocytic cells, including cells with dendritic morphology. J Immunol 1983, 131(4):1714-1727.

32. Carrasco YR, Batista FD: B cells acquire particulate antigen in a macrophage-rich area at the boundary between the follicle and the subcapsular sinus of the lymph node. Immunity 2007, 27(1):160-171.

33. Junt T, Moseman EA, lannacone M, Massberg S, Lang PA, Boes M, Fink K, Henrickson SE, Shayakhmetov DM, Di Paolo NC, et al: Subcapsular sinus macrophages in lymph nodes clear lymph-borne viruses and present them to antiviral B cells. Nature 2007, 450(7166):110-114.

34. Qi H, Egen JG, Huang AY, Germain RN: Extrafollicular activation of lymph node B cells by antigen-bearing dendritic cells. Science 2006, 312(5780):1672-1676.

35. Batista FD, Harwood NE: The who, how and where of antigen presentation to B cells. Nat Rev Immunol 2009, 9(1):15-27.

36. Huang NN, Han SB, Hwang IY, Kehrl JH: B cells productively engage soluble antigen-pulsed dendritic cells: visualization of live-cell dynamics of B cell-dendritic cell interactions. J Immunol 2005, 175(11):7125-7134.

37. Link A, Zabel F, Schnetzler Y, Titz A, Brombacher F, Bachmann MF: Innate immunity mediates follicular transport of particulate but not soluble protein antigen. J Immunol 2012, 188(8):3724-3733. 
38. Bergtold A, Desai DD, Gavhane A, Clynes R: Cell surface recycling of internalized antigen permits dendritic cell priming of B cells. Immunity 2005, 23(5):503-514.

39. Le Roux D, Le Bon A, Dumas A, Taleb K, Sachse M, Sikora R, Julithe M, Benmerah A, Bismuth G, Niedergang F: Antigen stored in dendritic cells after macropinocytosis is released unprocessed from late endosomes to target B cells. Blood 2012, 119(1):95-105.

40. Cubas R, Zhang S, Kwon S, Sevick-Muraca EM, Li M, Chen C, Yao Q: Viruslike particle (VLP) lymphatic trafficking and immune response generation after immunization by different routes. J Immunother 2009, 32(2):118-128.

41. Graham FL, Smiley J, Russell WC, Nairn R: Characteristics of a human cell line transformed by DNA from human adenovirus type 5. J Gen Virol 1977, 36(1):59-74.

42. Arguelles MH, Orellana ML, Castello AA, Villegas GA, Masini M, Belizan AL, Gonzalez Ayala S, Vera OD, Glikmann G: Measles virus-specific antibody levels in individuals in Argentina who received a one-dose vaccine. J Clin Microbiol 2006, 44(8):2733-2738.

doi:10.1186/1472-6750-12-80

Cite this article as: Borio et al:: Antigen vehiculization particles based on

the Z protein of Junin virus. BMC Biotechnology 2012 12:80.

\section{Submit your next manuscript to BioMed Central and take full advantage of:}

- Convenient online submission

- Thorough peer review

- No space constraints or color figure charges

- Immediate publication on acceptance

- Inclusion in PubMed, CAS, Scopus and Google Scholar

- Research which is freely available for redistribution 